Current Issues of Mass Communication, Issue 24 (2018)

Journal homepage: http://comstudies.org

https://doi.org/10.17721/2312-5160.2018.24.22-32

UDC 007: 304: 001

\title{
Utilisation of Uses and Gratifications Theory and Newspapers by Citizens for Political Information Purposes
}

\author{
Alex Eloho Umuerri \\ Department of Mass Communication, Benson Idahosa University, \\ PMB 1100, University Way, Off Upper Adesuwa Road, GRA, Benin City, Nigeria \\ * Corresponding author's e-mail address: alexungng@yahoo.com
}

\begin{abstract}
One of the theories in mass communication studies, namely the media uses and gratifications theory has always attracted the attention of scholars in researches. This article explored the effectiveness of the utilisation of the uses and gratification theory in newspapers by citizens for the political information purposes.

The study employed the survey research method to explore two Nigerian newspapers, namely Urhobo Voice, and Urhobo Vanguard; the research questions posed from the theoretical premise of the uses and gratifications theory.

The result indicated that the newspapers were not the leading sources of political information for the residents; instead, radio played the leading role as attested to in this study. Secondly, voter education was found as the most helpful factor, as indicated by respondents.

The study recommends establishment of daily newspapers as a way to bridge this gap of citizens not attesting to the use of the newspapers as their leading source of political information, and also to ensure that journalists provide adequate coverage on issues of election campaigns and government-related political matters for the enlightenment of citizens.
\end{abstract}

KEYWORDS: theory; theoretical synopsis; uses and gratifications theory; political information; newspapers use by citizens. 


\title{
Теорія використання та задоволення і преса - застосування громадянами для політичних інформаційних цілей
}

\author{
Алекс Елохо Умуеррі, Департамент масових комунікаиій Університету Бенсон Айдахоса \\ у Бенін-Сіті, старший викладач, РhD
}

\section{Резюме}

Одна 3 теорій у дослідженнях масової комунікації, а саме: теорія використання та задоволення - завжди привертала увагу науковців. У цій роботі досліджено ефективність застосування громадянами теорії використання та задоволення у газетах для політичних інформаційних цілей.

Дослідження використовувало метод дослідження для вивчення двох нігерійських газет, а саме Urhobo Voice i Urhobo Vanguard; дослідницькі питання були поставлені на теоретичному підгрунті теорії використання та задоволення.

Результати дослідження показали, що газети не були провідними джерелами політичної інформації для мешканців, а натомість провідну роль відігравало радіо. По-друге, освіта виборців була визнана найбільш корисним фактором, як зазначено респондентами.

Дослідження рекомендує створення щоденних газет як спосіб подолання розриву між інформаційними потребами громадян та наразі доступною пресою, підвищення використання газет як джерела політичної інформації, а також забезпечення журналістами адекватного висвітлення питань, пов'язаних із виборчими кампаніями та урядовою діяльністю для просвітництва громадян.

Ключові слова: теорія; теоретичний опис; теорія використання та задоволення; політична інформація; використання преси громадянами.

\section{Умуерри А.Э. Теория использования и удовлетворения и пресса - применение граж- данами для политических информационных целей.}

Одна из теорий в исследованиях массовой коммуникации, а именно: теория использования и удовлетворения - всегда привлекала внимание ученых. В этой работе исследована эффективность применения гражданами теории использования и удовлетворения в прессе для политических информационных целей.

Метод исследования применен для изучения двух нигерийских газет, а именно Urhobo Voice и Urhobo Vanguard; исследовательские вопросы были поставлены на теоретической основе теории использования и удовлетворения.

Результаты исследования показали, что газеты не были ведущими источниками политической информации для жителей, а ведущую роль играло радио. Во-вторых, образование избирателей было признано наиболее полезным фактором, как указано респондентами.

Исследование рекомендует создание ежедневных газет как способ преодоления разрыва между информационными потребностями граждан и прессой, повышение использования газет как источника политической информации, а также обеспечение журналистами адекватного освещения вопросов, связанных с избирательными кампаниями и правительственной деятельностью для просвещения граждан.

Ключевые слова: теория; теоретическое описание; теория использования и удовлетворения; политическая информация; использование прессы гражданами. 


\section{Introduction}

Globally, the mass media have been known to carry out the traditional functions of surveillance of the environment, correlation of the responses of the entire society to the environment and transmission of social inheritance from one generation to another (Lasswell 1948; Becker, 1982).

In different parts of the world (in the advanced and developing world), the media - newspapers, radio, television, and the new media - have continued to play these three functions in society. It is in recognition of these functions of the mass media in society that scholars have developed all kinds of theories to explain existing and unfolding phenomena in the media. According to Babbie (1989), a theory is a generalized and more or less comprehensive set of statements relating to different aspects of some phenomenon. McQuail (1987) says a theory consists of "sets of ideas of varying status and origin which explain or interpret some phenomenon'. Furthermore, a theory is a body of knowledge that explains existing phenomenon in society.

In mass communication, theories explain certain phenomena that you find in the media. It is in this direction that we need to understand the relevance of uses and gratifications theory of mass communication. Littlejohn (1992) has observed that the approach focuses on the consumer, the audience member rather than the message. This approach imagines the audience member to be a discriminatory user of the media. It views the members of the audience as actively utilizing media contents, rather than being passively acted upon by the media. Folarin (2005, p.91) provides further insight to this theory when he notes that the question is on who uses which contents from which media under which conditions and for what reasons. The scenario according to Folarin is:

1. An individual has some needs related to communication.

2. He/she selects the media that appear likely to satisfy those needs.

3 . He/she selectively consumes the content.

4. An effect may or may not occur (Kunczick, 1988).

The Theory is captured by Katz $(1959$, p.2) in this way “... It is the program that asks the question, not "what do the media do to people? But "what do people do with the media? The theory is based on the following assumptions as stated by Blumler and Katz (1974, p.23):

1. The audience is assumed to be an active user of mass media.

2. Each audience member must discern which medium will best gratify his or her needs for a given use.

3. Media outlets compete with other sources of gratification and media cannot satisfy all human needs.

4. Empirical data assessment can help determine the goals of mass media consumers since users are self-aware enough to accurately describe their motives.

5. Judgements about the cultural relevance of mass media must be withheld in order to avoid speculation on popular culture

According to Katz et al (1974, p.23) the framework for the uses and gratifications theory is as follows:

(1) The audience is conceived of as active, i.e an important part of mass media use is assumed to be goal directed.

(2) In the mass communication process much initiative in linking need gratification and media choice lies with the audience member. This places a strong limitation on theorizing about any form of straight-line effect of media content on attitudes and behaviour.

(3) The media compete with other sources of need satisfaction.

(4) Many of the mass media use can be derived from data supplied by individual audience members themselves. 


\section{Theoretical Synopses}

A cursory look at the tenet of the theory as stated by Littlejohn (1992); Folarin (2005, p.91); Katz (1959, p.2); Katz and Blumler (1974, p.3) will reveal that the uses and gratifications theory places emphasis on the audience or user of messages/information. In other words, instead of the media-radio, television and newspaper affecting/influencing the behaviour of the audience, it is the latter that use the information in the media for personal gains or readers or viewers/listeners attend to the respective media.

While foregoing attempt to give a synthesis of knowledge about the uses and gratifications theory, it is important to assess the criticisms levelled against this theory.

\section{Criticisms of the Theory}

There are a number of criticisms or perceived shortcomings of this theory, and those are mentioned and briefly explained below.

1. The general approach was criticized as being too behaviourist and functionalist. It has also failed to provide much successful prediction or causal explanation of media choice and use (McQuail, 1984) cited in (McQuail, 2010, p.425)

2. The extent to which audience behaviour is guided by specific and conscious motives has always been in dispute. Babrew (1988) proposed that we think more in terms of "interpretive frameworks based on experience. Thus, some audience choice is meaningful in terms of such frameworks, while exposure is based on only habit and reflex and may be considered unmotivated (Rubin, 1984) cited in (McQuail, 2010, p.426)

\section{The Problem}

Arising from the propositions of the uses and gratifications theory, this study set out to investigate the possibilities which existed for the examination of a local phenomenon in Nigeria. Specifically, the resident indigenes of Delta Central Senatorial District, in Delta State, Nigeria comprising eight Local Government Areas (which have been identified in the methodology section of this paper) have been known to be politically active in Nigerian politics, however, the extent of the citizens use of the mass media, and specifically in this context, newspapers published by individuals/indigenes in the senatorial district for political purposes has not been established. Therefore, are the citizens aware of these newspapers in their senatorial District? If they are aware, do they read the newspapers? What gratifications (political) do they derive from reading the newspapers? Or are the newspapers used in this study the leading sources of political information? These and other pertinent issues formed the basis of investigation in this study.

\section{Objectives of the study}

This study was undertaken to: ascertain the awareness of the newspapers by citizens; and the readers of the two Nigerian newspapers, in the Delta central senatorial District of Delta State, Nigeria.

Other objectives were the determination of: the relative importance of the two Nigerian newspapers as providers of gratifications for readers; the newspapers and other sources as purveyors of political information; political information that citizens found useful in the newspapers.

\section{Research Questions} lows:

A number of questions were therefore formulated from the propositions of the theory as fol-

1.What is the awareness and readership of the newspapers?

2.What gratifications do readers derive from the newspapers?

The above mentioned research questions were derived from assumption two (2) of Blumler and Katz (1974) uses and gratifications theory which states that: "Each audience member must discern which medium will best gratify his or her needs for a given use"

3. What are the sources of political information used by readers?

This research question originated from assumption three of Blumler and Katz (1974) uses and Gratifications Theory: "Media outlets compete with other sources of gratification...' 
4.What political information do respondents/readers find most useful in the newspapers?

This research question is from assumption two (2) of Blumler and Katz (1974) Uses and Gratifications Theory which states that: each audience member must discern which medium will best gratify his or her needs for a given use".

\section{Literature Review}

An important aspect of this study is the literature on political information or communication as a basis for understanding use of newspapers.

Political Information and the Mass Media

Political information has been conceptualised by Mcleod, Kosicki and Mcleod (1994) as involving the exchange of symbols and messages between political actors and institutions, the general public and news media which have consequences for the political system.

In addition, Gurevitch and Blumler (1997) have said political information is the process by which politically relevant information is transmitted from one part of the political system to another. Elaborating on this further, Pfestch $(2004$, p.47) has observed that:

From the point of system theory, constant exchange between occupants of boundary roles of two social systems (politics and media) lends to political communication, where there is political and media roles with both transcending purely sectional interest.

This made Pfestch (2001) to advocate two sides to political information as stated below:

1. Party-oriented political communication which deals with political actors in favourable political competition with other parties; and

2. Media-oriented political information which is on favourable media coverage and unspecified support from media audience.

The mass media in a geographical entity can influence the character, form and content of political information (Mcleod, Kosicki and Mcleod, 1994). Political communication as Philips, Roberts and Benjamin (1999) have explained is done through television programmes, radio, newspapers and news magazine and these come in the shape of documentaries, personality profiles, features, news, cartoons, editorials and others.

In Nigeria, political reportage has become commonplace as political debates by registered and approved parties, public opinion polls (POP) on likely outcomes of election results, syndicated reports conventions and campaigns of political parties and others, have emerged as forms of the mass media through reportage/coverage of these events has made it possible for the fate of political parties and politicians to be partly determined by the media.

\section{Research methods}

This study employed the survey research method in investigating readers' attitude towards the two newspapers of Urhobo Voice and Urhobo Vanguard for political information purposes. Wimmer and Dominick (2003) state that it is flexible and popular among media researchers. Besides, it is the most suitable for the purpose of this study to ascertain readers' attitude and use of the newspapers. The newspapers used for this study are Urhobo Voice and Urhobo Vanguard both published in Delta Central senatorial District of Delta state, Nigeria. The newspapers are owned by individuals within the Urhobo ethnic group. Urhobo Voice is published by Uvoh Amroma International Ltd and owned by Ogbemure, M. Imene, while Urhobo Vanguard is published by Urhobo Vanguard Press limited, Ughelli. Urhobo Voice is published weekly, secondly, Urhobo Vanguard is published every forth nightly. These newspapers are published only in English language. In addition to the two mentioned published newspapers in the Delta Central senatorial District, we also have Urhobo Times published in Ughelli However, out of these three newspapers Urhobo Voice and Urhobo Vanguard were used for this study, because they are consistent in outing and easily available in the newsstands for readers.

The respondents used for the study are resident citizens of Delta Central Senatorial District 
in Delta State, Nigeria who are Urhobo indigenes. The Urhobo indigenes in this senatorial district are from eight local Government areas as follows: Ethiope East with literate population of 135,369; Ethiope West 126,958; Okpe 84,118; Sapele 120,148; Udu 97,361; Ughelli North 211,693; Ughelli South 115,903; and Uvwie 140,872, (National Population Census Figures, 2006) Ethiope East local government area has its headquarters in Isiokolo; Ethiope West, Oghara; Okpe, Orerokpe; Sapele, Sapele; Udu, Otor-Udu; Ughelli North, Ughelli; Ugheli South, OtuJeremi; and Uvwie, Effurun. These eight local Government Areas constitute Delta Central Senatorial District of Delta state, Nigeria, and the headquarters of these local government areas were used for the study to determine readers' attitude and use of the Urhobo Voice and Urhobo Vanguard newspapers. Available sampling technique was used to draw sample from the literate population of civil servants and others. Because respondents share demographic characteristics used for the study, available sample was thought necessary as it provided a representative picture of the literate population with different levels of education. It was assumed that the sample size would represent the reading population. Also, the population was made up of all Urhobo newspapers published in English language in Delta Central senatorial District of Delta State, Nigeria.

The National Population Census Figures (2006) provide information on the population of literate residents in Isiokolo, Oghara, Orerokpe, Sapele, Otor-Udu, Ughelli, Otu-jeremi, and Effurun, and a total of 500 copies of Questionnaire were administered with each local government headquarters having 50 questionnaires. For Ethiope East in Isiokolo thirty-six (36) copies of questionnaire were completed and returned; fifty-five (45) for Oghara; fourty (40) for Orerokpe, fourty-six (46) for Sapele; thirty-eight (38) for Otor-Udu; Fourty-four (44) for Ughelli; thirtyeight (38) for Otu-jeremi, and fourty-seven (47) for Effurun. Therefore, a total of three hundred and thirty-four questionnaires were used from the eight local government council areas.

The method of data analysis employed was the frequency counts and percentage distribution.

\section{Results and discussion}

From the questionnaire administered we present the results as follows:

The data in table 1 indicates that 185 or $55.39 \%$ which was the highest were of the 31-61 age bracket.

Table 2 showed that majority 172 or $51.50 \%$ of respondents were females.

Data in table 3 revealed that 244 or $73.05 \%$ respondents had post-secondary education training.

Results in table 4 reveals that there is a high level of awareness of Urhobo Voice and Urhobo Vanguard with 258 or $77.24 \%$ of respondents.

The data in table 5 however indicate that 212 or $63.48 \%$ respondents which is the highest do not read the newspapers.

From table 6 the most gratification readers derived from the newspapers was for education with 49 or $40.16 \%$ as attested to by respondents.

Table 7 reveals that 108 or 32.33 respondents which was the highest number affirmed that radio was the most sought-after source through which they got political information when compared to the newspapers used for the study and other sources.

Results from table 8 indicate that 59 or $48.36 \%$ of respondents which was the highest said they found voter education most useful aspect of political information in the newspapers.

The study investigated four research questions. On the first research question which was on awareness, and the readership of the newspapers (see tables 4 and 5) it was revealed that the awareness of the newspapers is high among respondents, 258 or $77.24 \%$.

Sixty-three respondents or $18.86 \%$ were not aware of the newspapers, while 13 or $3.90 \%$ respondents were not sure if they were aware of the newspapers or not. The results indicate that respondents have a positive perception of the newspapers. Another leg to this research question 
was to find out if respondents read the newspapers or not. However, the highest number of 212 or $63.48 \%$ of the respondents said they did not read the newspapers, while 122 or $36.12 \%$ respondents said they read the newspapers.

On research question two, which was to find out the gratification respondents derived from the newspapers forty-nine or $40.16 \%$ respondents claimed they were gratified from the perspective of education, this was followed by information which was 28 or $22.96 \%$ of respondents; political awareness and utility 27 or $22.13 \%$, and entertainment value 18 or $14.75 \%$. In response to research question three which was on the sources of political information by respondents, the leading source was radio which was 108 or $32.33 \%$, followed by internet/social media and other sources which was 76 or $22.76 \%$, television 61 or $18.26 \%$, Urhobo Voice 48 or $14.37 \%$, Urhobo Vanguard 26 or $7.78 \%$, and politicians/political parties 15 or $4.50 \%$ This result has confirmed the often held view in research circles that radio is a key source for political information for voters. This result is therefore in line with the findings of Ojebode, et al, according to Media for Democracy (2018) in their study entitled: "Broadcast Media Readiness and Engagement of Electoral Issues Towards the 2019 General Elections in Nigeria". This study revealed the crucial role of radio and television as "still major sources of electoral information and education for majority of Nigerians'. The importance of radio has also been stressed by the National Democratic Institute as an important means of information which provided civic education for citizens in Southern Sudan as far back as 2009 (NDI reports, 2008, p.I).

Finally, research question four sought to find out the political information respondents found most useful in the two publications. From the results, voter Education was the most preferred by respondents with 59 or $48.36 \%$, followed by government political matters which was 34 or $27.87 \%$, and election campaigns 29 or $23.77 \%$.

From the result, the highest number of respondents did not read the newspapers, this is an indication of confirmation of the poor reading habits of citizens in the developing society, when compared to those who read the newspapers. It is interesting to note that the leading gratification citizens derived from the newspapers was for education. This has confirmed the often-held position that citizens crave for education materials in the print media especially on political matters.

When the two newspapers were compared to other sources from which respondents got political information, it was revealed that the newspapers were not the leading sources of political information, instead radio was the most sought after, followed by internet/social media/other sources. The implication of other sources is that these could include: the church, market places, friends or relatives as sources of political information.

Lastly, the political information which respondents found most useful showed that citizens yearn for education of the eligible voter in the senatorial district.

\section{Conclusions}

This article investigated the effectiveness of the uses and gratifications theory for newspaper use by citizens in Delta central senatorial district of Delta state, Nigeria. Some major concerns have emerged from this study, and these are in the areas of poor reading habits of citizens in the developing society; and also, the fact that the newspapers used for the study were not the leading sources of political information by citizens; and that other political matters were not usually given adequate attention by the publications. It is therefore important that in these newspapers, adequate information and education are played up in order to create political awareness for citizens.

The following recommendations were made:

1. Readers of newspapers should be properly enlightened on democratic issues/matters so that they can have political awareness and utilize the information in newspapers to actively participate in the election process. This bounden duty is for journalists to concentrate more on creating political awareness so that readers will benefit from such reports. 
2. There is need to have more newspapers in senatorial districts in Nigeria that would be published daily to represent interest of citizens in the geographical entities. This should make publications readily available to citizens in order to avoid citizens using or making use of other sources of political information. It is the duty of individuals and groups to ensure that more publications hit the streets so that political matters can be included in such publications for citizens to read.

3. Reportage and Issues of election campaigns should be properly explained in these newspapers so that readers can understand. This onerous task lies with journalists covering the political beat.

\section{Tables}

Table 1: Age Distribution of Respondents.

\begin{tabular}{|l|l|l|l|}
\hline SN & Age & Frequency & $\%$ \\
\hline 1 & $18-30$ years & 119 & 35.62 \\
\hline 2 & $31-61$ years & 185 & 55.39 \\
\hline 3 & 62- Above & 30 & 8.99 \\
\hline & TOTAL & 334 & 100 \\
\hline
\end{tabular}

Table 2: Sex Distribution of Respondents.

\begin{tabular}{|l|l|l|l|}
\hline SN & Sex & Frequency & $\%$ \\
\hline 1 & Male & 162 & 48.50 \\
\hline 2 & Female & 172 & 51.50 \\
\hline & TOTAL & 334 & 100 \\
\hline
\end{tabular}

Table 3: Distribution of Respondents Education.

\begin{tabular}{|l|l|l|l|}
\hline SN & Education & Frequency & $\%$ \\
\hline 1 & No Formal Education & 09 & 2.70 \\
\hline 2 & Primary School & 15 & 4.49 \\
\hline 3 & Secondary School & 66 & 19.76 \\
\hline 4 & Post School & 244 & 73.05 \\
\hline & TOTAL & 334 & 100 \\
\hline
\end{tabular}

Table 4: Awareness of Newspapers by Respondents.

\begin{tabular}{|l|l|l|l|l|l|}
\hline SN & Variables & Urhobo Voice & Urhobo Vanguard & Total & \% \\
\hline 1 & Yes & 172 & 86 & 258 & 77.24 \\
\hline 2 & No & 18 & 45 & 63 & 18.86 \\
\hline 3 & Not Sure & 5 & 8 & 13 & 3.90 \\
\hline & Total & 195 & 139 & 334 & 100 \\
\hline
\end{tabular}


Table 5: Respondents Reading Attitude Toward the Newspapers.

\begin{tabular}{|l|l|l|l|l|l|}
\hline SN & Variables & Urhobo Voice & Urhobo Vanguard & Total & \% \\
\hline 1 & Agree/Yes & 78 & 44 & 122 & 36.52 \\
\hline 2 & Disagree/No & 117 & 95 & 212 & 63.48 \\
\hline & Total & 195 & 139 & 334 & 100 \\
\hline
\end{tabular}

Table 6: Gratifications Readers Derive from The Newspapers.

\begin{tabular}{|l|l|l|l|l|l|}
\hline SN & Gratifications & Urhobo Voice & Urhobo Vanguard & Total & $\%$ \\
\hline 1 & Education & 36 & 13 & 49 & 40.16 \\
\hline 2 & $\begin{array}{l}\text { Political Aware- } \\
\text { ness and Utility }\end{array}$ & 16 & 11 & 27 & 22.13 \\
\hline 3 & Entertainment & 09 & 09 & 18 & 14.75 \\
\hline 4 & Information & 17 & 11 & 28 & 22.96 \\
\hline & Total & 78 & 44 & 122 & 100 \\
\hline
\end{tabular}

Table 7: Respondents Sources of Political Information.

\begin{tabular}{|l|l|l|l|}
\hline SN & Sources & Frequency & \% \\
\hline 1 & Urhobo Voice & 48 & 14.37 \\
\hline 2 & Urhobo Vanguard & 26 & 7.78 \\
\hline 3 & Radio & 108 & 32.33 \\
\hline 4 & Television & 61 & 18.26 \\
\hline 5 & Politicians/Political Parties & 15 & 4.50 \\
\hline 6 & Other Sources/ Social Media & 76 & 22.76 \\
\hline & Total & 334 & 100 \\
\hline
\end{tabular}

Table 8: Political Information Respondents find Most Useful.

\begin{tabular}{|l|l|l|l|l|l|}
\hline SN & Political Information & Urhobo Voice & Urhobo Vanguard & Total & \% \\
\hline 1 & Voter Education & 41 & 18 & 59 & 48.36 \\
\hline 2 & Election Campaigns & 19 & 10 & 29 & 23.77 \\
\hline 3 & Government Political Matters & 18 & 16 & 34 & 27.87 \\
\hline & Total & 78 & 44 & 122 & 100 \\
\hline
\end{tabular}

\section{References}

1. Babbie, E. (1989), The Practice of Social Research, $5^{\text {th }}$ edition, California, Wadsworth Publishing Company.

2. Becker, L. (1982), "The Mass Media and Citizen Assessment of Issue Importance”, in D.C. Whitney et al (eds.), Mass Communication Review Yearbook, Vol. 3, Beverly Hills, C.A. Sage, pp. 521-36.

3. Bittner, J. R. (1989), Mass Communication: An Introduction, $5^{\text {th }}$ ed., New Jersey, Prentice-Hall Incorporated. 
4. Blumler, J (1979), The Role of Theory in Uses and Gratifications Studies Communication Research, California, Sage Publications.

5. Blumler, J.G. and Gurevitch, M. (2000), "Rethinking the Study of Political Communication", in Curran, J. and Gurevitch, M. (eds.), Mass Media and Society, $3^{\text {rd }}$ edition, London, Arnold Group.

6. Blumler, J. and Katz, E. (1974), The Uses of Mass Communication, California, Sage Publications.

7. Esser, F., Reinemann, C. and Fan, D. (2001), "Spin Doctors in the United States, Great Britain, and Germany: Media Communication about Media Manipulation", The Harvard International Journal of Press/Politics, no. 6(1), pp.16-45.

8. Federal Republic of Nigeria Official Gazette (2009), Census Figures, vol. 96, Feb., 2, Abuja, Federal Government Printer.

9. Folarin, B. (2005), Theories of Mass Communication: An Introductory Text, Ibadan, Bakinfol Publications.

10. Gurevitch, M. and Blumler, J.G. (1997), "Linkages Between the Mass Media and Politics: A model for the Analysis of Political Communication System", in Curran, J., Gurevitch, M.; and Woolacot. J. (eds.), Mass Communication and Society, London, Edward Arnold Publishers.

11. Katz, E (1959), "Mass Communication Research and the Study of Popular Culture: An Editorial Note on A Possible Future for Studies in Public Communication", pp.1-6.

12. Katz, Blumler, and Gurevitch (1974), "Utilisation of Mass Communication by the Individual", The Uses of Mass Communication: Current Perspective on Gratifications Research, Katz, and Blumler (eds.), Beverly Hills, Sage, pp.19-32.

13. Katz, Gurevitch, and Haas (1973), "The Use of the Mass Media on Important Things", American Sociological Review, no. 38, pp.164-181.

14. Kunczick, M. (1988), Concepts of Journalism: North and South, Bonn, Frederick Elbert-Stiftung.

15. Lasswell, H.D. (1948), "The Structure and Function of Communication in Society", Bryson, L. (ed.), The Communication of Ideas, New York, Harper and Row, pp. 32-51.

16. Littlejohn, S.W. (1992), Theories of Human Communication, $6^{\text {th }}$ ed., New Mexico, Wadsworth Publishing Company.

17. McLeod, J.M.; Kosicki, G.M. and McLeod, D.M. (1994), "The Expanding Boundaries of Political Communication Effects", in Bryant, J. and Zillman, D. (eds.), Media Effects Advances in Theory and Research, New Jersey, Lawrence Erlboun Associate Publisher.

18. McQuail, D. (1987), Mass Communication Theory: An Introduction, $2^{\text {nd }}$ ed., London, Sage Publication.

19. McQuail, D. (1984), Mass Communication Theory: An Introduction, Ist. ed., London, Sage Publication.

20. McQuail, D. (2010), Mass Communication Theory, $6^{\text {th }}$ ed, London, Sage Publication.

21. McQuail, Blumler, and Brown (1972), "The Television Audience: A revised Perspective", in McQuail, D. (ed.), Sociology of Mass Communication, Hamondsworth, Penguin, pp.135165.

22. Media 4 Democracy NG (2018), Study Assesses Media Readiness for 2019, Election Coverage, Lagos, Institute for Media and Society.

23. National Population Commission Census Report (2006), Abuja, Federal Republic of Nigeria.

24. NDI Reports (2008), Radios Help provide Civic Education in Sudan, Washington, National Democratic Institute.

25. Negrime, R. and Lilleker (2002), "The Professionalisation of Political Communication: Continuities and Change in Media Practice", in European Journal of Communication, September, 17(3), pp. 305-323. 
26. Nord, L.W. (2001), “Americanisation vs the Middle Way: New Trends in Swedish Political Communication", The Harvard International Journal of Press/Politics, no. 6(2), pp.11-119.

27. Okigbo, C. (1990), "Sources of Political Information in a Rural Nigerian Community", Africa Media Review, 6.3, pp.65-77.

28. Pfestch, B. (2001), "Political Communication Culture in the United States and Germany", The Harvard International Journal of Press/Politics, 6(1), pp.46-67.

29. Phillips, D., Roberts, N., and Benjamin, S.A. (1999), "Political Communication Through Newspaper Advertisement: The case of the 1999 Presidential Election in Nigeria", Niser Monograph Series, no. 10.

30. The Constitution of The Federal Republic of Nigeria (1999), Lagos, The Federal Government Press.

31. Urhobo Voice (2018), November, 28.

32. Urhobo Voice (2018), December, 3.

33. Urhobo Vanguard (2018), Tuesday, $20^{\text {th }}$ November $-4^{\text {th }}$ December, 2018.

34. Wimmer, R.D. and Dominick, J.R. (2003), Mass Media Research: An Introduction, $7^{\text {th }}$ ed. Bellmont, C.A., Wardworth Publishing Company. 